\title{
Analysis on the Status Quo of Jingdong's Global Purchase of Overseas Warehouse
}

\author{
Xiaowei Zhu ${ }^{1,2, a}$ and Zhuocheng Li \\ ${ }^{1}$ Wuhan Technology And Business University, China,HuBei,Wuhan,430065 \\ ${ }^{2}$ Hubei Business Service Development Research Center,China,HuBei,Wuhan,430065 \\ a81892036@qq.com
}

Keywords: Cross-border e-commerce; Logistics mode; Overseas warehouse

\begin{abstract}
China's cross-border e-commerce logistics mode mainly includes domestic storage and delivery, and overseas storage and delivery. The latter mode has become the mainstream mode of cross-border e-commerce logistics in recent years. This paper studies the logistics mode of Jingdong's global purchase and the situation of building the warehouse abroad, analyzes its advantages and disadvantages, and puts forward the rationalization plan to provide some reasonable suggestions for the transformation and upgrading of the cross-border e-commerce enterprises in China.
\end{abstract}

\section{Introduction}

With the wave of mobile Internet, China's e-commerce industry has gradually developed many different subdivision and vertical domains from a single domestic trade type. Cross-border business is one of the fastest growing areas. In our country, big business giants and Internet giants have joined the fierce competition in the cross-border e-commerce industry. In addition to this competition, there are still some vertical businesses and star startups. In recent years, the mode of overseas sellers or platforms to build and deliver goods has gradually become the mainstream operation mode of the large cross-border e-commerce, but the problems such as the immature mode, high cost and low logistics speed are urgent to be solved.

\section{An Overview of Related Theories}

An Overview of Cross-border E-commerce Logistics. Cross-border e-commerce logistics refers to the fact that in the transaction activity, after a commodity has reached a transaction, it can be passed from one country or region to another country or region through international express delivery, international freight, or postal freight. Its main logistics mode is divided into two kinds: the first is to purchase goods overseas and store and ship in the country; the second is that overseas sellers or platforms store or ship overseas.

An Overview of Overseas Warehouse. After the cross-border e-commerce enterprise has developed to a certain scale, the original logistics mode has not been able to meet the current requirements of scale, which has spawned a large number of enterprises to build warehouses in the countries where the goods are located, and deliver goods directly from the source. At present, due to a number of problems in cross-border e-commerce logistics, general cross-border e-commerce companies have adopted a model of combining overseas warehouses to optimize their own logistics and warehousing systems. Overseas acquisitions have gradually become the mainstream trend. At present, China's cross-border e-commerce industry has two modes, namely self-built mode and cooperation mode with third parties.

\section{Introduction of Jingdong Global Purchase's Logistics and Overseas Warehouse}

Through Jingdong's global logistics and warehousing system, the cost of Jingdong's global purchase has been effectively reduced, and Jingdong's global purchase also copy Jingdong's most advantageous "warehouse integration" mode to overseas. 
Logistics Management Strategy and Layout. The Jingdong group has actively laid out the construction of the domestic logistics system, and has made remarkable achievements in strengthening the internal management of its own logistics and improving the ability of distribution service. As shown in table 2-1, the Jingdong logistics key business growth chart shows that more than 300 large warehousing bases have been built throughout the country by 2017, more than 8000 logistics distribution stations and self pick-up sites. At the same time, we should strengthen the distribution of the domestic logistics business, strive to develop international logistics business, realize the strong union with the international top freight forwarding enterprises, and greatly improve the timeliness of the cross-border logistics. At the same time, for the overseas businesses on the platform, the Jingdong provided them with international transportation, cross-border bonded warehouses, domestic distribution and other cross-border logistics solutions.

Table 2-1 Jingdong logistics key business growth table

\begin{tabular}{|c|c|c|c|}
\hline $\begin{array}{c}\text { Years } \\
\text { Category }\end{array}$ & 2015 & 2016 & 2017 \\
\hline $\begin{array}{c}\text { Logistics Distribution } \\
\text { Station (100) }\end{array}$ & 68 & 75 & 86 \\
\hline Large storage base & 216 & 268 & 338 \\
\hline
\end{tabular}

Through the Jingdong's global logistics and warehousing system, Jingdong's global purchase cost has been effectively reduced. Jingdong global purchase also copies the most advantageous "warehousing and distribution integration" mode to overseas. Through the big data platform of the Internet of things, the sales of various commodities in different areas are prejudged in advance, and the corresponding quantity of goods will be made in advance the commodity customs clearance and distribution to the nearest city warehouse, which effectively reduces the circulation and cost of cross-border commodities, and significantly improves the timeliness of cross-border commodity transportation.

Construction of Partners. In addition to developing overseas warehouse direct mail mode, Jingdong also builds warehouses in major domestic bonded zones to maximize efficiency. The establishment of warehouse in the free trade zone and direct delivery can not only enjoy the preferential policies of the free trade zone, but also shorten the logistics time and form standardized operation of standardized goods. In addition, the Jingdong has reached strategic cooperation with the Deutsche Post DHL group to strengthen the free global cooperative logistics warehousing system with the group's infrastructure and logistics systems abroad. Moreover, Jingdong is also working with major global brands to help them build local services, such as after-sales service maintenance in key overseas markets. Overseas warehouse as a new cross border e-commerce logistics mode, Jingdong has also accelerated the construction of overseas warehouses.

The Combination of Bonded Warehouse and Overseas Warehouse Construction. The crossborder e-commerce focuses on the global market, the transaction subject is no longer limited to the same country or region, the complexity of the transaction link, but also determines the complexity of the logistics link. The cross-border logistics also breaks through the national concept, including not only the logistics links of the exporting countries, but also the international logistics, the logistics and distribution of export countries, and the customs and commodity inspection links of the importing and exporting countries. In the specific cross-border e-commerce transactions, cross border logistics often use a variety of logistics mix. The combination of overseas direct mail and overseas warehouse construction refers to the use of two cross-border logistics modes in the implementation of cross-border logistics, which is intended to make use of the advantages of different cross-border logistics models to achieve complementary effects.

\section{Problems Existing in the Jingdong's Global Purchase of Overseas Warehouse}

At present, due to some problems in cross-border e-commerce logistics, Jingdong has adopted a combination of overseas warehousing to optimize its own logistics and warehousing system. 
Overseas warehouse building has become a mainstream trend, but there are still problems to be solved.

Higher Transport Costs and Unstable User Experience. In the overseas, a large number of personal express packet direct mail not only brings great pressure to customs clearance, but also cannot achieve the scale benefit advocated by the industry. The database of the transshipment company does not connect with the customs database. Once the number of parcels is increasing, it may lead to the delay of customs clearance, the delay of parcels, the loss of parcels and so on, which seriously affect the consumer's shopping experience.

Large Construction Funds Demand and Long Construction Cycle. Enterprises or sellers who build their own overseas warehouses must have sufficient cash flow, strong talent reserves and large volume of sales data to support the construction and operation costs of overseas warehouses. With its large area, large construction funds, long construction time, complex management and so on, the overseas warehouse has caused not all the enterprises with the abundant financial resources of the Jingdong, and can spend a lot of time and funds to establish and operate overseas warehouses. Overseas warehouses not only need to invest a lot of capital and apply mature management methods to maintain, but also need to invest long-term human resources costs. Such harsh conditions cannot be expected for start-ups or businesses with inadequate financing or limited capital.

High Warehouse Management Cost. In recent years, domestic e-commerce enterprises are keen on "making festivals" promotion. Many sales promotion festivals make the inventory management of goods more difficult, and they need to be different from the usual stock when they are promoted. When no promotion is promoted, the warehouse efficiency is too low and the enterprises lack effective means of inventory and supply chain management. External warehouses have become a stumbling block to the development of enterprises.

Miscellaneous Third-Party Warehouse Logistics Service. The third-party companies that provide overseas warehousing and logistics services have different professional standards and service quality. The logistics timeliness and storage standards will also be miscellaneous. In the course of transportation, goods are misplaced and lost. Due to the difference of express laws and regulations at home and abroad, the compensation of e-commerce enterprises is also uneven. When selecting third-party overseas warehousing suppliers, attention should be paid to whether management is standardized and whether there is a scientific and efficient management system.

\section{Suggestions on Jingdong's Global Purchase of Overseas Warehouse}

The Combination of the Private Logistics and the Third-Party Logistics. Overseas warehouses are shipped by logistics provided by third party partners. Jingdong is responsible for docking logistics warehousing systems and customs clearance systems worldwide. After the goods are transported to China, the goods are transported to the Jingdong's own warehouse directly by the seamless docking of the logistics information system. The goods are delivered directly by the customs through the Jingdong express to the consumers. The Jingdong should change the current strong control of logistics and storage system, change the role of providing information system infrastructure and service, give professional things to the specialized third party suppliers to complete, do well the management of infrastructure construction and information service, and control the logistics and storage system on the software.

Choosing whether to Build a Warehouse Abroad or not According to Its Own Needs. The cross-border e-commerce enterprises should have a clear understanding of their own operating conditions and needs when choosing the logistics and warehousing schemes. At the same time, it is also necessary to realize that although there are many advantages in overseas construction, they should not have no disadvantages, so we should choose independently according to their own conditions, and do not blindly follow the wind. We should make a choice under the premise of considering all explicit and implicit costs. Only small scale order start-ups and sellers are temporarily not suitable for overseas building model, because the construction and operation of overseas warehouse need to consume a lot of money and energy. If the warehouse has a large stock pressure for a long time, it will be very bad for the capital turnover of the enterprise. To sum up, the 
construction and operation of overseas warehouses is very demanding for all aspects of the enterprise. A cross-border business enterprise is to invest the limited funds and energy into the construction and operation of the overseas warehouse, or to focus on brand building and commodity operation to improve the competitiveness of the enterprise, which is a major strategic choice to be made after the decision of the enterprise.

Training Risk Awareness to Improve the Ability of Risk Control. The establishment of a cross-border e-commerce enterprise association to foster risk awareness and attach importance to risk control capabilities is extremely important. Cross-border e-commerce companies should strengthen their learning and research on customs, laws and regulations, and fiscal and taxation policies in overseas target countries, and be successful in establishing overseas positions. The feasibility study will make accidental risks and invisible risks as predictable and controllable as possible. Pre-misconduct on the stock of goods or promotion failures may result in a large area of inventory retention. Therefore, companies should pay attention to the strategic judgment based on the demand forecast, effectively use big data and the enterprise cloud to make accurate forecasts of commodity consumption trends. Not only that, companies can also use the above technologies to strengthen the precise control of overseas warehouse inventory and structure, and effectively improve integrated risk control capabilities.4.4 customizing the warehousing logistics system according to its own needs.

Customizing Warehousing Logistics System according to Their Needs. Cross-border ecommerce companies must first have a clear understanding of their own needs and have a clear grasp of the characteristics and profit targets of the goods they sell. At the same time, each ecommerce company's product composition types are different. For example, Jingdong Mall's 3C electrical business is its ace business, and the vertical e-commerce business's product focus is even more varied. Qualified third-party warehousing and logistics suppliers can help customers to customize the most suitable warehousing and logistics system and warehouse space layout according to their specific conditions and customer needs. Whether or not a third-party supplier can customize a warehousing and logistics system suitable for the enterprise according to the specific needs of the enterprise and its own situation is of utmost importance. The supplier and the enterprise (customer) need to work together and collaborate together. After the customization program is completed, the e-commerce company can determine whether the customized solution is suitable for itself and whether it is operational based on its own needs and sales.

\section{Conclusions}

The cross-border e-commerce and its warehousing logistics systems are closely related and inseparable. They both belong to the cross-border e-commerce industry and are two sides of a coin, making them affect and restrict each other. A strong and efficient warehousing and logistics system will provide strong support for the development of cross-border e-commerce. To better promote the vigorous development of the cross-border e-commerce industry in China, we need to plan from the whole. We must pay attention not only to platform construction, brand building, and commodity operation, but also to the infrastructure-warehousing logistics system that supports the former. Enterprises need to continuously improve the platform operation mode, product characteristics and quality, and cross-border storage and logistics model, improve the efficiency of warehousing logistics systems, improve customer service quality in order to promote the overall development of the company.

\section{Acknowledgement}

Fund Project: Hubei Provincial Collaborative Innovation Center for Modern logistics and business (Project No.2011A201307)

Fund Project: MOE (Ministry of Education in China) Project of Humanities and Social Sciences (Project No.14YJCZH154) 
Funding team: Wuhan Technology and Business University Academic Team (Project No. XSTD2015004)

\section{References}

[1] Libin E and Yongwen Huang: New Way of International Trade: The Latest Research on CrossBorder E-commerce[J], Journal of Dongbei University of Finance and Economics, 2014(2): 2231.

[2] Jingjing Li and Minghui Wang: Analysis of China's B2C Cross-Border E-Commerce Logistics Mode[J], Journal of Commercial Economics, 2018(2):13-14.

[3] Zhixiang Wang: Research on Risk and Countermeasures of Cross-Border E-Commerce Business[J], Value Engineering, 2018(1):7-9.

[4] Guie Sun: Research on the Development of B2B Cross-Border E-Commerce Logistics[J], Modern Marketing(the last ten days of a month), 2018(1):12-13.

[5] Binbin Zhou and Yue Xia: Study on the Status Quo and Problems of Cross-Border Export Trade of Medium and Small Enterprises in Zhejiang[J], Modern Business Trade Industry, 2018(1):2426.

[6] Shuaishuai Fu: Analysis of Jingdong' Global Purchase Development Based on System Dynamics[J], Journal of Shanghai Business School, 2017(12):4-5.

[7] Wei Li: Analysis and Market Research of Cross Border E-Commerce Logistics Mode in China[J], Rural Economy and Science-Technology, 2017(11):34-35.

[8] Xiaomeng Gao, Jiarui Su, Yongjuan Wang, Jing Cao and Yan Rong: The Impact of RMB Devaluation on Overseas Purchasing and Countermeasures[J], Modern Economic Information, 2017(11):67-70.

[9] Xiaheng Zhang: Jingdong: Building a Cross-Border E-Commerce Ecosystem[J], Business Management, 2016(11):14-15. 